\title{
What are tilosomes? An update and new perspectives ${ }^{1}$
}

\section{Halisson Rafael Kedrovski2* (1) and Maria das Graças Sajo ${ }^{2}$ (1)}

Received: August 3, 2018

Accepted: November 7, 2018

\begin{abstract}
Characterization of tilosomes and study of their development revealed that they are similar to the cell wall ingrowths of transfer cells. Roots from Anathallis sclerophylla were used to examine the development, histochemistry and ultrastructure of tilosomes using light, confocal and electron microscopy (both SEM and TEM). Tilosomes initiate as cellulosic papillae in the root elongation zone, increasing the apo/symplast surface throughout the wall-membrane apparatus. Both the development and structure of tilosomes and velamen strips appear similar to the reticulated and flange cell wall ingrowths of Vicia faba transfer cells. We suggest two functional phases for tilosomes: a) in young tissues they increase the symplast connection and thus improve outside-inside transport; and b) in mature tissues they direct solutes to passage cells. Both the physiology and the genetic mechanisms controlling the ontogeny of tilosomes remain obscure.
\end{abstract}

Keywords: autofluorescence, callose, cell wall biochemistry, ontogeny, oriented wall deposition, waxes

\section{Introduction}

\section{A tilosome historic and current view}

The tilosomes known as protrusions or excrescences (Pridgeon et al. 1983; 1999) actually are wall ingrowths (WI) on the inner periclinal wall of the endovelamen cells that lay adjacent to the exodermis passage cells (Fig. 1). They occur in the aerial roots of specific epiphytic orchids. These branched lignified structures (Porembski \& Barthlott 1988; Pridgeon et al. 1999; Stern 2014) were first described in Bulbophyllum careyanum (Chatin 1856) and Sobralia liliastrum (Oudemans 1861) and interpreted as adaptations that developed in association with the epiphytic habit in the Orchidaceae (Pridgeon 1983; Benzing 1990). Their function seems to be directly associated with water balance in the plant, reducing the evapotranspiration or promoting the condensation of atmospheric moisture (Benzing et al. 1982). Besides their ecophysiological importance (Zotz 2016), they are important taxonomic characters in the groups in which they occur and define seven morphological types (Pridgeon et al. 1983), although others can also occur. Tilosomes predominate in the Polystachyeae tribe, subtribes Sobraliinae, Coelogyninae, Laeliinae, Pleurothallidinae, Bulbophyllinae, Lycastinae, and Maxillariinae (Pridgeon 1983; Pridgeon et al. 1983). Within the Pleurothallidinae, the largest orchid subtribe (Karremans 2016), the presence of tilosomes can be considered a plesiomorphic characteristic however frequent and showing a high morphological diversity (HR Kedrovski, unpubl. res.).

The ultrastructure of developed tilosome was first shown for Sobralia macrantha (Benzing et al. 1982). Subsequent anatomical studies pointed out their taxonomic importance (Stern \& Judd 2001; 2002; Stern et al. 2004; Carlsward et al. 2006; Figueroa et al. 2008; Stern \& Carlswards 2009; Silva et al. 2010; 2015; Pedroso-de-Moraes et al. 2012; Andreota et al. 2015) but did not show when or how the tilosomes are formed and neither correlate their morphology with the

1 This article is part of the first author $\mathrm{PhD}$ thesis.

2 Programa de Pós-graduação em Ciências Biológicas (Biologia Vegetal), Departamento de Botânica, Universidade Estadual Paulista

"Júlio de Mesquita Filho", 13506-900, Rio Claro, SP, Brazil

* Corresponding author: h.r.kedrovski@hotmail.com 
wall-membrane apparatus of transfer cells (TC) (Talbot et al. 2002; McCurdy et al. 2008). Unlike other types of structure where WI are observed such as in seeds (Monjardino et al. 2013; Rocha et al. 2014; Arun-Chinnappa \& McCurdy 2016), phloem parenchyma (Arun-Chinnapa et al. 2013; Nguyen \& McCurdy 2017; Nguyen et al. 2017), giant-cells in nematode feeding tubes (Cabrera et al. 2014; Miyashita \& Koga 2017), phi cells (Fernandez-Garcia 2009; Melo 2011; Idris \& Collings 2015), tracheoidal idioblasts (Burr \& Barthlott 1991; Leroux et al. 2011), haustorium flange cells (Fineran 1998; Fineran \& Calvin 2000) and glands (Gama et al. 2016; Tozin \& Rodrigues 2017; Wilson et al. 2017), the development, ultrastructure and wall composition of the tilosomes have not yet been described. According to Pridgeon (Stern 2014), the wall deposition that forms the tilosome in the endovelamen cells, is oriented early in development by plasmodesmos between an exodermis passage cell and an endovelamen cell. This author concluded that: "much more study is needed to determine the function and ontogeny of tilosomes and whether or not the environment plays a role in the extent of their development".

\section{Materials and methods}

\section{Light microscopy}

Root apices of Anathallis sclerophylla (Lindl.) Pridgeon \& M.W.Chase were fixed in FAA 70 (Johansen 1940), stored in alcohol $70 \%$, dehydrated in terc-butanol series and imbedded in Paraplast. Longitudinal and transversal serial sections were cut at $20 \mu \mathrm{m}$ using a rotary microtome. The permanent slides were stained with $0.05 \%$ toluidine blue (Feder \& O'Brien 1968) and safrablue (Bukatsch 1972; Kraus \& Arduin 1997), mounted in Entellan. Photomicrographs were taken under a light microscope (DM 4000B, Leica Microsystem, Wetzlar, Alemanha) with attached camera (DFC 450, Leica Microsystem), through LAS 4.0 software (Leica Aplication Suite, Leica) in the Photomicrograph Laboratory at the Botany Department, UNESP - Rio Claro.

\section{Scanning electron microscopy}

The fixed samples were dehydrated in alcoholic series, and then in a critical point dryer (EM CDP 300 Leica Microsystem, Wetzlar, Gemany), sputter-coated with gold (EM SCD 500 Leica Microsystem, Wetzlar, Germany) and observed in SEM (JSM 6390 LV Jeol, Tokio, Japan) in the Electron Microscopy Central Laboratory of the Federal University of Santa Catarina - UFSC.

\section{Transmission electron microscopy}

The root tips were fixed in $2.5 \%$ glutaraldehyde in $0.1 \mathrm{M}$ sodium phosphate buffer at $\mathrm{pH} 7.2$ for 24 hours
(Kraus \& Arduim 1997). The material was post-fixed in osmium tetroxide (OsO 4) $1 \%$ in $0.1 \mathrm{M}$ phosphate buffer, $\mathrm{pH} 7.2$ for 4 hours at room temperature (Bozzola \& Russel 1999). After being dehydrated with increasing series of acetone, the material was infiltrated and embedded in a polymer mixture (Araudite, and Epon DDSA). The ultrathin transverse sections were taken by an ultramicrotome, stretched and attached to the grids, counterstained with uranyl acetate and lead citrate, according to Reynolds (1963) procedures, observed and photographed in a TEM (Tecnai Spirit - FEI Company) in the Electron Microscopy Center of the Biosciences Institute, UNESP - Botucatu.

\section{Confocal microscopy}

Roots previously fixed and stored were included in polyethylene glycol, $20 \mu \mathrm{m}$ transversely and longitudinally sectioned using a rotary microtome in the Laboratory of Morphology of the Botany Department of UNESP-RC. Sections were stained separately with calcofluor to mark cellulose and aniline blue for callose, according to Kraus \& Arduin (1997). The slides were observed in the Leica SP5 AOBS Point Scanning confocal Microscope from the UNESPRC Electronic Microscopy Laboratory. The fluorophores were excited at $405 \mathrm{~nm}$ with near UV diode and the emission wavelengths were collected between 415 and $448 \mathrm{~nm}$ (blue). Lignin and waxes could be visualized by autofluorescence when respectively excited at $488 \mathrm{~nm}$ by Argon laser collected between 491 and $563 \mathrm{~nm}$ (green), and at $633 \mathrm{~nm}$ by HeNe laser collected between $522-622 \mathrm{~nm}$ (red). The laser intensity was set to the minimum necessary for imaging $(\sim 20 \%)$ in order to increase the specificity and definition of the wall components localization. The images were obtained in the 3 channels (blue, green and red) in z-stacking with 10 steps for three-dimensional reconstruction.

\section{Samples}

All fresh samples were obtained from vegetative clones under cultivation in UNESP-RC Botany Department greenhouses.

\section{Results and discussion}

\section{Tilosome development, morphology and wall biochemistry}

At the elongation zone of Anathallis sclerophylla root apex (Fig. 2), tilosomes develop as cellulosic inconspicuous papillae; on the inner primary cell wall of the endovelamen, adjacent to the exodermis passage cells (Figs. 2G, 3A-D). Papillae synthesis is associated with the presence of mitochondria and RER (Fig. 3). During cell differentiation, the tilosomes undergo lignin impregnations (Fig. 2G-I) to assume their final structure (Figs. 1, 4). Within the 


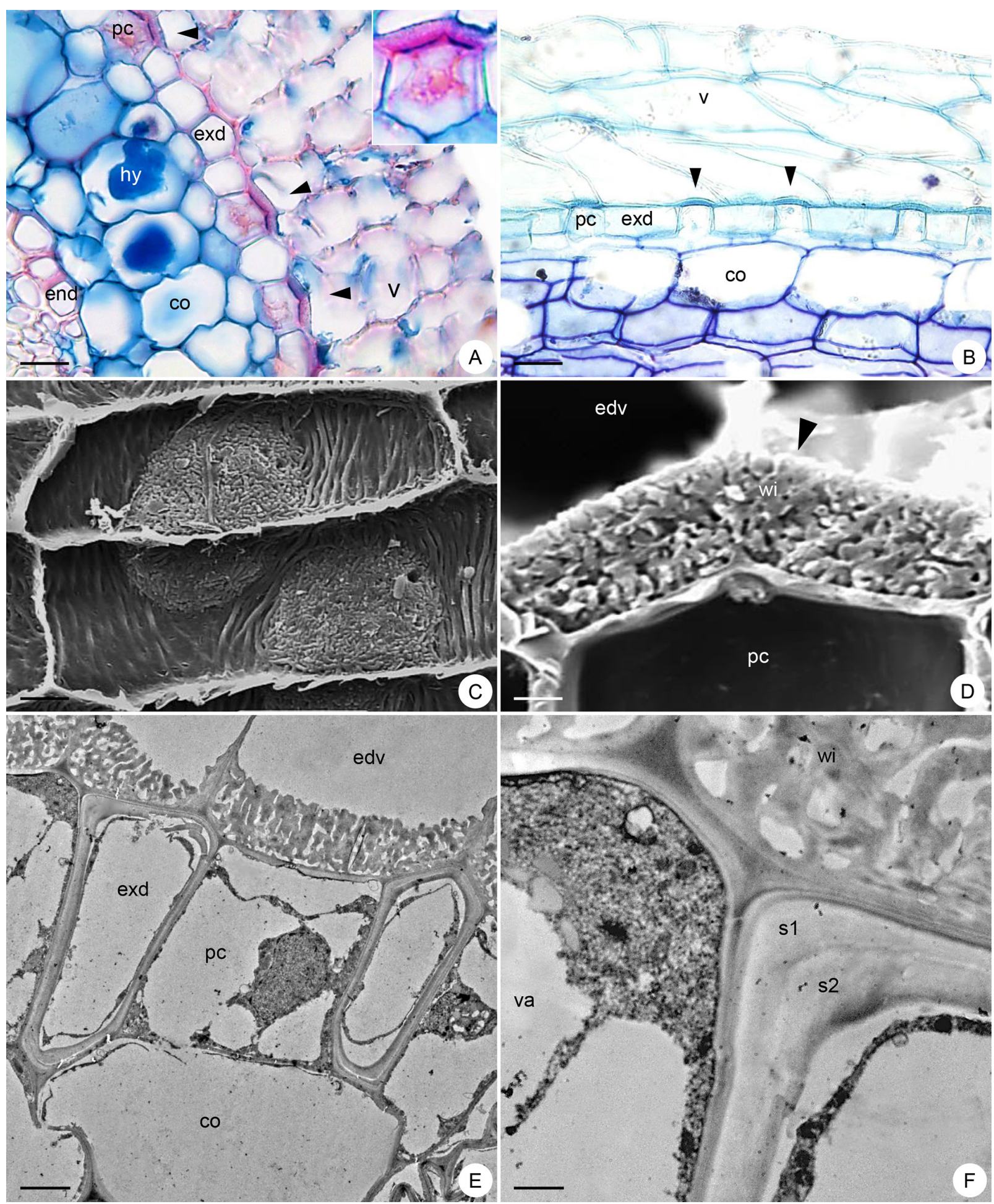

Figure 1. Tilosome morphology in Anathallis sclerophylla root. A-B Light Microscopy. C-D SEM. E-F TEM. A. Cross section of differentiated roots stained with safrablue, showing "O" thickened endodermis cells (end), cortical cells (co) with pelotons (hy), dead exodermis cells (exd), passage cells of dense cytoplasm (pc), tilosomes (arrowhead) with a thin blue primary wall and the stratified velamen (v). B. Longitudinal section stained with toluidine blue, showing by metachromasy the lignified walls (green) in velamen (v), tilosome (arrowhead) and exodermis (exd); note the cortex cellulosic walls (anil blue) (co) and the difference between the common and the passage cells of exodermis. C-D. Paradermic (C) and cross section (D) showing the tilosomes (arrowhead) adjacent to the exodermis passage cells (pc) and the reticulated and flange patterns of the endovelamen (edv) WIs. E-F. Velamen-exodermis complex showing dead cells in the endovelamen (edv), WIs lumen directed to environment, common exodermis cell (exd) with two layers of secondary wall (s1, s2), vacuolated passage cells (pc) with conspicuous nucleus, mitochondria, ribosomes on an electron-dense matrix and vesicles adjacent to the tonoplast,. Scale bars: $25 \mu \mathrm{m}(\mathrm{A}), 50 \mu \mathrm{m}(\mathrm{B}), 10 \mu \mathrm{m}(\mathrm{C}), 3 \mu \mathrm{m}(\mathrm{D}), 5 \mu \mathrm{m}(\mathrm{E})$. 

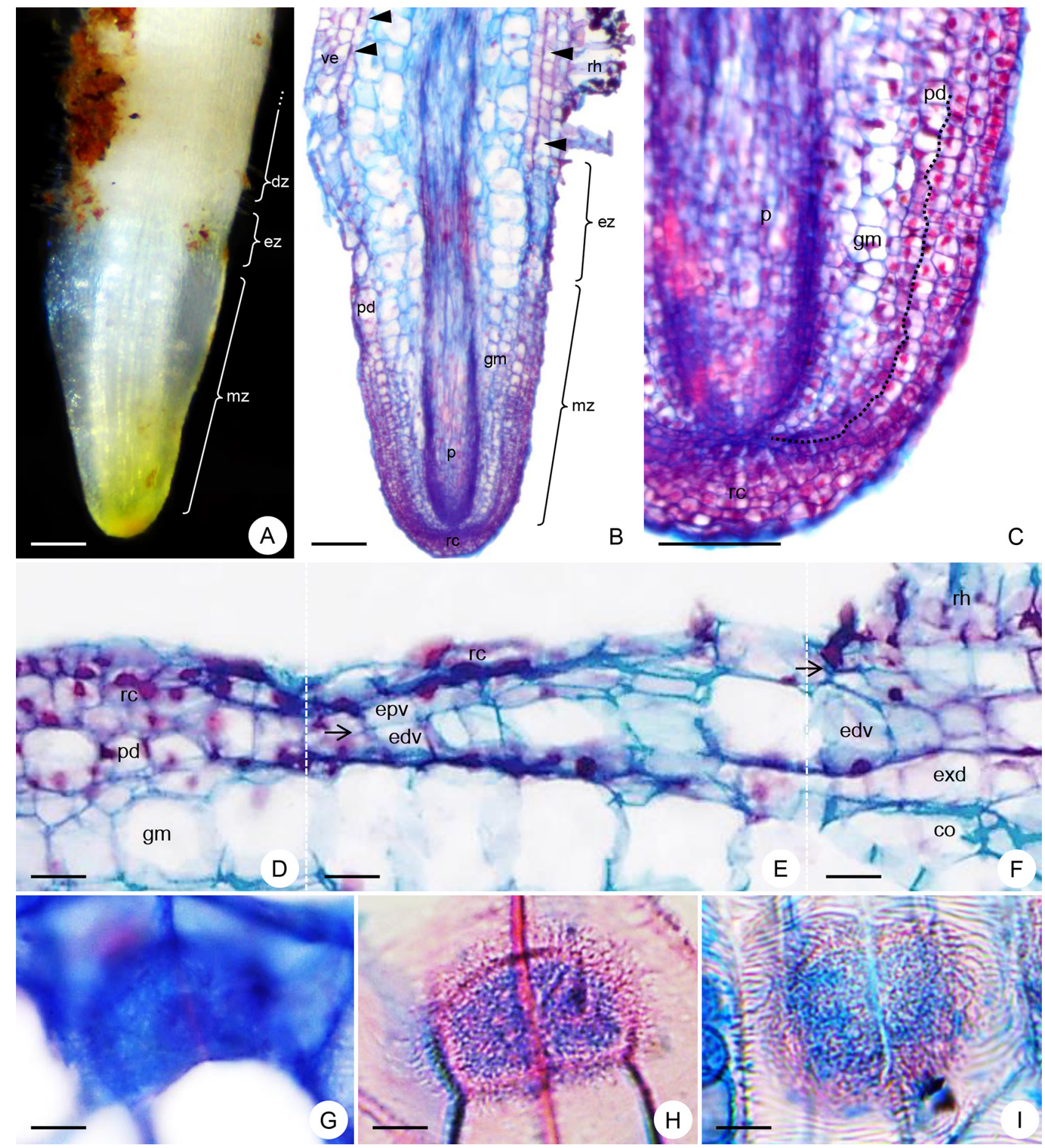

Figure 2. Macro (A) and micromorphology (B-I) of Anathallis sclerophylla roots. Longitudinal (B-I) sections of the apex, showing the epidermis and cortex (D-F) and the tilosomes (G-I) development. There are three zones in the apex (A-B): 1. Meristematic (mz) (C) with isodiametric protodermis cells (pd), ground meristem (gm) of elliptical cells and procambium (p) of fusiform cells (B-C); 2. Short elongation zone (ez) at the boundary of the root cap (D) with primary walled cells (B); it is characterized by the increase of the cellular volume in the median region of the ground meristem (causing a compression in the exodermis layer $(\mathbf{E})$ ), and by the first division of the protodermis originating the endo and epivelamen (edv, epv); 3. Differentiation zone (dz) (D-F), with a second division in the epivelamen, the development of root hairs (rh) and the progressive tissue specialization (A-B). The tilosome (G) begin as small, papillose-like regions in the inner wall of some endovelamen cells laying adjacent the exodermis passage cells. The secondary wall deposition in these cells follow the orientation of the primary WI (G), leading to the tilosomes or velamen stripes formation (H-I). The dotted line indicates the boundary between protoderm and root cap, and the arrows indicate the velamen cell divisions. Scale bars: $120 \mu \mathrm{m}(\mathrm{A}-\mathrm{B}), 50 \mu \mathrm{m}(\mathrm{C}), 25 \mu \mathrm{m}(\mathrm{D}-\mathrm{F}), 10 \mu \mathrm{m}$ (G-I). 
elongation zone of the root apex (Fig. 2A-B, E), we can see that: 1. the protodermis is exposed to the external environment, once no root cap is observed; 2. periclinal divisions on the protodermis cells give rise to a multilayred velamen, composed by an epi and endovelamen; 3. cells of the outer layer of the ground meristem, which give rise to the exodermis, are collapsed due to the rapid grow of the cortical cells. The protodermal cells that give rise to WI possess a larger nuclear region and fewer vacuoles in the cytoplasm if compared to the ground meristem that gives rise to the root cortex (Fig. 3A-C).

Study of the changes in morphology and wall composition during tilosome development, using light, confocal and transmission microscopy has revealed that

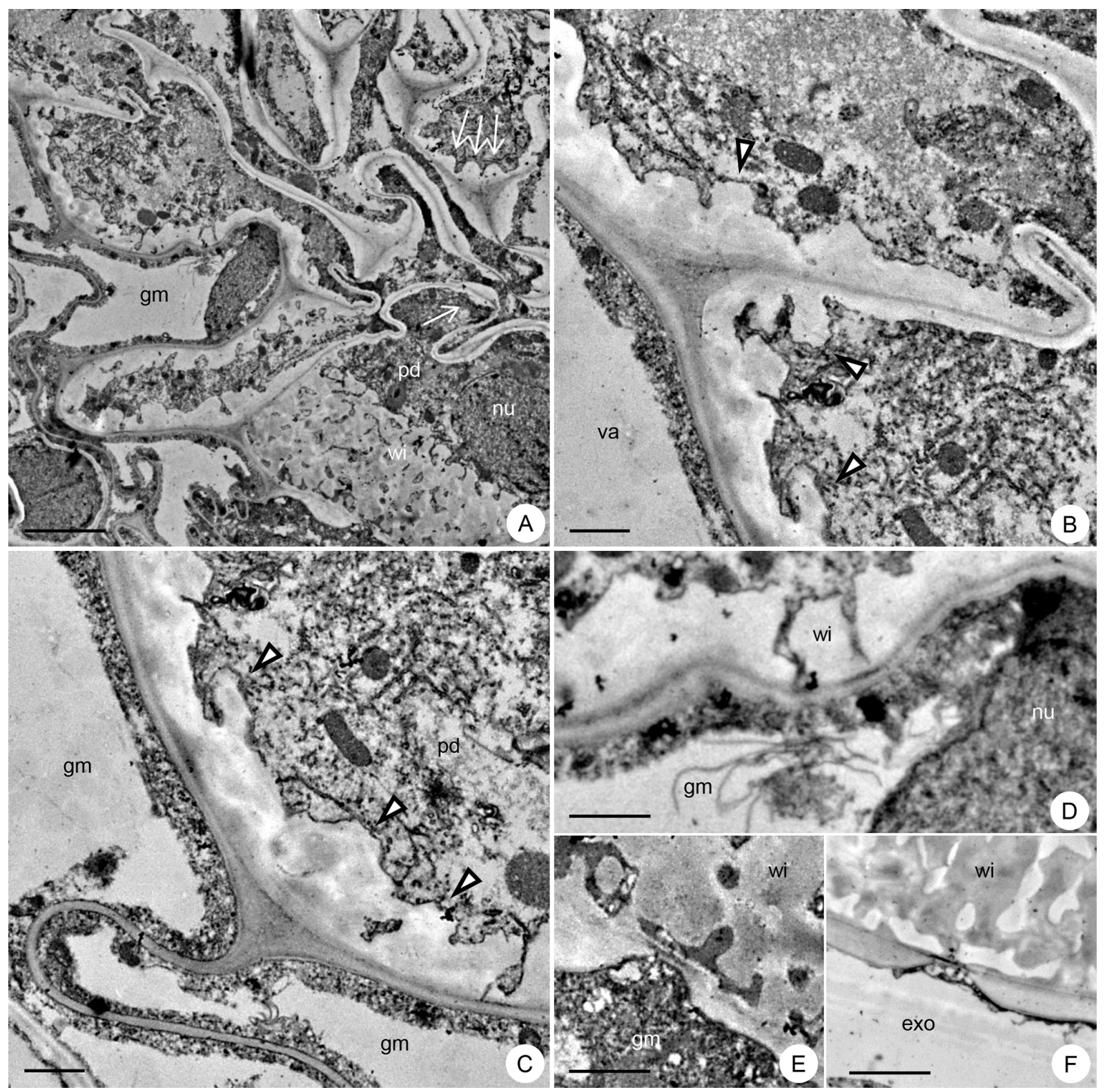

Figure 3. Ultrastructural details of the protodermis and ground meristem during the tilosomes formation in Anathallis sclerophylla root. The asynchronous WIs deposition (A) in the inner protodermis layer (dp) is noted by small papillae (arrowhead) of fibrillar material in the inner cell wall adjacent to the ground meristem (gm) (A-C). Each papillae is a precursor of the wall system that characterize the reticulate tilosome. In the outer protodermis layers (A), the cells are poorly vacuolated and vesicles/organels rich; they possess flange-like projections (arrows) on the walls, that will give rise to the characteristic velamen strips. The protodermis cells that develop walls ingrowth had increased nuclear region (nu) and few vacuoles in the cytoplasm compared to those which give rise to the cortex in ground meristem. The papillae wall synthesis is closely related to the presence of mitochondria and RER (A-C) and to the increase of cell surface. The ground meristem cells possess large vacuolated (va) and thin walls. The limit between the velamen cell walls and tilosome is not visible. Velamen-exodermis are continuous through the tilosome- exodermis (exo) passage cell; these cells possess many plasmodesmata both before (D-E) and after cell differentiation (F) that can or not be occluded by callose. Scale bars: $5 \mu \mathrm{m}(\mathrm{A})$, $\operatorname{2um}(\mathrm{F}), 1 \mu \mathrm{m}(\mathrm{B}, \mathrm{C}, \mathrm{D}, \mathrm{E})$. 


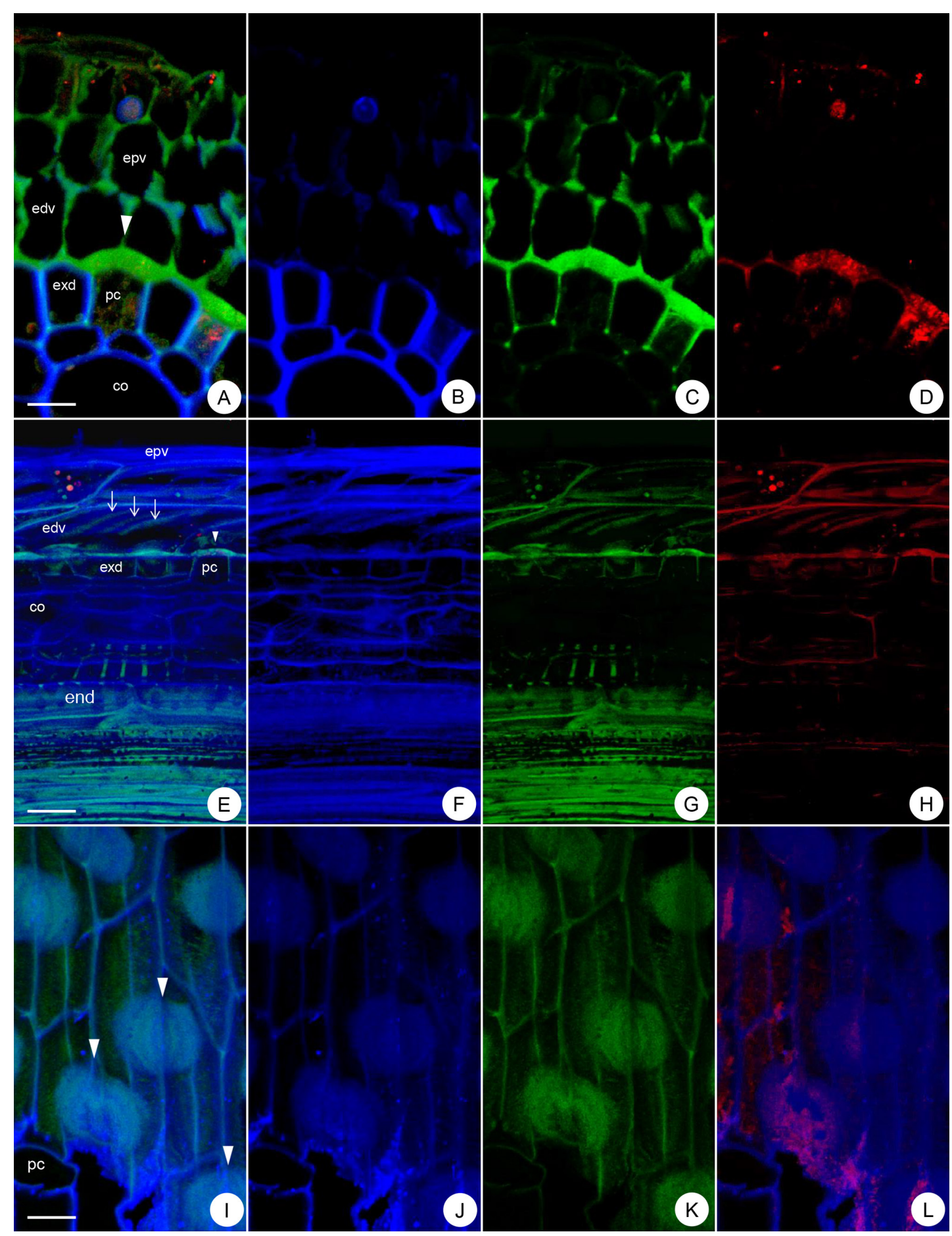

Figure 4. Three-dimensional z-stack reconstructions of cross (A-D), and longitudinal (E -L) sections of Anathallis sclerophylla roots stained with calcofluor $(\mathbf{A}-\mathbf{D})$ and aniline blue (E-L) fluorophores, in order to demonstrate the wall compositions. Cellulose (A-B) and callose $(\mathbf{F}, \mathbf{G})$ shown in blue and lignin in green $(\mathbf{C}, \mathbf{G}, \mathbf{K})$ are the main walls constituents, although waxes could also be evidenced by autofluorescence when excited by low intensity red light in argon diode (D, H, L). By intense fluorescence, cellulose can be observed in cortical parenchyma (co) and in "O"-thickened cells of exodermis (ex), except for the outer periclinal wall of the passage cells (A-B). Lignin is found in endovelamen (edv), velamen stripes (arrow) (A), tilosomes (arrowhead) (C), “ $\cap$ ”- thickened exodermis cells (C, G), intercellular spaces of outer cortical parenchyma $(\mathbf{C})$, spiral thickenings of internal cortical parenchyma (G), endodermis (en) and vascular cylinder (E, G). Callose occurs in all cell walls, with the highest concentration in the epivelamen (epv) (E-F), in the plasmodesmata around the tilosomes $(\mathbf{J})$ and in the inner layer of the cortical parenchyma including endodermis (F). Waxes (suberin and cutin) occur in a smaller quantity when compared to the fluorescence of other polymers; it is concentrated in the outer layers of the velamen (D, H) but it is diffuse in the tilosomes (D), in the " $\cap$ "-thickened exodermis cells, intercellular spaces of the cortical parenchyma, endodermis and phloem (H). Note the occurrence of infections by algae and fungi. Scale bars: $30 \mu \mathrm{m}(\mathrm{E}-\mathrm{H}), 15 \mu \mathrm{m}(\mathrm{A}-\mathrm{D}), 10 \mu \mathrm{m}(\mathrm{I}-\mathrm{L})$. 
the papillary shape of the tilosomes at early development stages, are similar to those of the wall-membrane-apparatus of cotyledon TCs in Vicia faba (Gunning \& Pate 1969; Offler et al. 2002). Its cellulosic composition may contribute to the out/inward transport over the root peripheral region that is in contact with the external medium and spatially distant from the vascular cylinder. Offler et al. (2002) argues that TC differentiation is strongly related both to the organ development stage and to the availability of solutes. When the tilosome WI is deposited, in the roots of A. sclerophylla, both the xylem and phloem are differentiated and thus able to perform transport in the elongation zone. As the cells differentiate the papillae (Fig. 2G-I), the velamen cell stripes and the exodermis cells undergo a progressive lignification (Fig. 4C, G, K), assisting the epidermal and exodermis cells to maintain their shape. The physiological properties of lignin (mechanical support, compressive strength and plant defense) (Zeier et al. 1999) support this interpretation. If so, the lignin is synthesized as a response to the potential collapse of the exodermis cells, in order to maintain the shape and volume of both the cortex and velamen cells. Benzing (1986) also pointed out that the lignified velamen and cortex cells are essential to prevent collapse and maintain the shape of aerial roots exposed to desiccation.

Callose is usually deposited in specialized walls (Chen \& Kim 2009) during the division, growth and differentiation of plant cells (Vatén et al. 2011) and can also appear in the plasmodesmata to regulate the cell-to-cell transport (Xie et al. 2012; Cui \& Lee 2016). In the root of A. sclerophylla, callose occurs in the cell walls of the outer velamen layers and tilosomes, in the plasmodesmata between exodermisvelamen and endodermis-cortical parenchyma cells (Fig. 4E-F, I-J). Callose deposition can be induced by injury, pathogen infections, presence of chitin and chitosan, presence of aluminum, ABA and salicylic acid (Luna et al. 2011; Nedukha 2015). There is an antagonism between the presence of callose and symplastic transport as this transport considerably decreases after callose is deposited (Lee \& Lu 2011). However, callose can be degraded, thereby reestablishing normal transport via the plasmodesmata opening. There is less or no callose deposition on the tilosomes plasmodesmata when compared to the adjacent flange walls (Fig. 4I-J). This indicates that these regions are capable of transport via the symplast.

Waxes, such as suberin and cutin (Nawrath 2002), are deposited on the cell wall of both aerial and underground plant organs. They reduce water loss and the penetration of incident UV, impose a barrier to apoplastic transport (Schreiber 2010) and protecting tissues against extreme temperatures, pathogens and herbivores (Ingram \& Nawrath 2011). The presence of a suberized lamella in the exodermis and endodermis cells, as evidenced in A. sclerophylla by autofluorescence under red laser (Fig. 4D, H, L), is very common (Enstone et al. 2003; Schreiber \& Franke 2011).
The occurrence of hydrophobic compounds in the tilosomes and velamen cell walls may be related to an absence of root cap, to a protection against photooxidation (Chomicki et al. 2015) and to the retention of water inside the organ. Cutin is also involved in the recognition of symbiotic hyphae (Murray et al. 2013), required for seed germination and for the establishment of the protocorm and seedling. In tangential view, we noticed gaps in the distribution of fat compounds in the inner periclinal walls of the endovelamen, specifically inside the tilosome (Fig. 2L), indicating water permeable regions.

After the complete root differentiation and expansion (Fig. 1), the velamen cells degenerate remaining leaving only the secondary walls and tilosomes connecting the thin walled exodermis passage cells to the environment. The velamen cells lack protoplasts, the lumen of tilosomes is reduced (Fig. 3F) due to their labyrinthine wall systems (Fig. 1C-F) and they are connected to the exodermis passage cells via plasmodesmata (Fig. $4 \mathrm{~J}$ ). The passage cells are small (Fig. 1B) and covered by primary walls at their anticlinal and inner periclinal sides (Fig. 1A), with a thin layer of irregular secondary wall on the outer periclinal side (Fig. 1E). They possess a conspicuous nucleus and vacuole that together limit the cytoplasm to the cell margin (Fig. 1E-F). The remaining exodermal cells, dead at maturity, are completely covered by secondary walls (Fig. 1F). The tilosome walls are seen to be impregnated with lignin as revealed by a positive reaction to toluidine blue (Fig. 1B) and to acidified phloroglucinol.

\section{Updating the interpretation of tilosomes}

Tilosome originate as cellulosic papillae in cells of the inner layer of the stratified protodermis, adjacent to the exodermis passage cells. The exodermis does not participate in the WI deposition. Tilosomes probably have two functional phases: in young tissues, they increase the symplast connection, facilitating transport over the outer root regions, like the wall-membrane apparatus of TC; while, in mature tissues, they protect, direct solutes to the passage cells, imposing a physicochemical barrier for pathogens and recognizing symbionts. The structure of tilosomes is related to biotic and abiotic factors: cellulose forms the thin primary wall, lignin gives support, waxes acts in water retention and organ defence and callose regulates transport in the symplastic sites. Although the function of water supply and balance is widely accepted for the tilosomes (Engard 1944; Dycus \& Knudson 1957; Sandford \& Adanlawo 1973; Pridgeon et al. 1983; Zotz \& Winkler 2013), the velamen cells are not interpreted as TC. It seems reasonable, since epidermal cells are alive when young and thus able to transport solutes; only when mature, the velamen cells form a saturated microclimate providing condensation and retention of atmospheric water through the WI hygroscopic and contact surfaces. 
The morphology of the reticulate and flange TC WIs are identical to those of the tilosomes (Pridgeon et al. 1983) and velamen stripes (Sandford \& Adanlawo 1973), corroborating the hypothesis of a dual physiological function. Two patterns of TC WIs are recognized (Talbot et al. 2002; McCurdy et al. 2008): the flange pattern, with curvilinear, rib-shaped non lignified projections that are more or less parallel, often bifurcated and fused that give rise to secondary wall ridges; and the reticulate pattern, that is a labyrinthine network of tubular projections, that start as small papillae emerging from the underlying wall at discrete loci (Talbot et al. 2001). These differences are related to the cytoskeleton. In the reticulate type, the WI coincides with the accumulation of actin filaments amongst the disordered microtubules arrangement; the rosettes concentration at specific points determines its cylindrical shape. The flange pattern originates by a cellulose deposition in parallel with the cytoplasm microtubules (Talbot et al. 2001; 2007a; b; Thompson et al. 2001). What distinguishes these two types of WIs in TC (flange or reticulate) is the presence or not of direct contact of the cell wall along its entire length, instead of the tilosomes architecture (Pridgeon 1983; Pridgeon et al. 1983). The lignification and, more importantly, the death of the velamen cells caused by aerial environment make this structure unique among those that possess WI keeping cells always alive.

\section{Conclusion}

\section{New perspectives}

Within the "Next-Generation Sequencing blast", the lack of information on the genetic mechanisms controlling tilosome formation should encourage comparison of the genomics of orchids with and without tilosomes, in order to clarify which gene(s) are being expressed in different root zones or tissues and to investigate how this control occurs. In this context, some questions remain unanswered such as: is the tilosome a phenotypic feature always expressed? When did this genetic expression appear, during subtribe history? Are there differences in the transport rate between root zones, tissues and roots with and without tilosomes? Studies on wall development and composition are of interest especially in tilosomes and other structures which depend on the oriented wall deposition. Disregarding easy serial sectioning, orchid roots are excellent models for cellular morphological and developmental studies, since they are easy to grow, to obtain, and to maintain under different stress conditions. Aseptic media, water supply, light or ionic stress and inoculations could delimit experiments designed to evaluate which factors interfere on the tilosomes development and to describe the occurrence of morphohistochemical and cytological alterations of roots under treatments. Essays using cellulose-synthase / callose-synthase / lignin-inhibiting drugs, hydrogen peroxide, chitosan, phytohormones, gene inactivation and cytoskeleton label may also be used to increase understanding of the mechanisms underlying wall structuring. Researches with labeled isotopes could reveal the physiology of transport (in or out) in young root tissues. Analyzes using light, transmission, scanning and confocal microscopy are indispensable to monitor the development, histochemical composition and the threedimensional morphology of wall ingrowths occurring in orchid roots.

\section{Acknowledgements}

We wish to thank Prof. Edwin W. Taylor, School of Biosciences, University of Birmingham, UK for his helpful assessment of our manuscript and Dra. Silvia Rodrigues Machado, UNESP, Botucatu, for her critical suggestions. HR Kedrovski thanks CAPES and MG Sajo thanks CNPq for your fellowships.

\section{References}

Andreota RC, Barros F, Sajo MG. 2015. Root and leaf anatomy of some terrestrial representatives of the Cranichideae tribe (Orchidaceae). Brazilian Journal of Botany 38: 367-378.

Arun-Chinnappa KS, McCurdy DW. 2016. Identification of candidate transcriptional regulators of epidermal transfer cell development in Vicia faba cotyledons. Frontiers in Plant Science 4: 1-12.

Arun-Chinnappa KS, Nguyen TTS, Hou J, Wu Y, McCurdy DW. 2013 Phloem parenchyma transfer cells in Arabidopsis - an experimental system to identify transcriptional regulators of wall ingrowth formation. Frontiers in Plant Science 4: 1-6.

Benzing DH. 1986. The vegetative basis of vascular epiphytism. Selbyana 9: $23-43$

Benzing DH. 1990. Vascular epiphytes: General biology and related biota. Cambridge, Cambridge University Press.

Benzing D, Ott D, Friedman W. 1982. Roots of Sobralia macrantha (Orchidaceae): structure and function of the velamen-exoderm complex. American Journal of Botany 69: 608-614.

Bozzola JJ, Russell LD. 1999. Electron microscopy: Principles and techniques for biologists. Boston, Jones and Bartlett Publishers

Bukatsch F. 1972. Bermerkungen zur Dopelfärbung Astrablau-Safranin. Mikrokosmos 61: 255

Burr B, Barthlott W. 1991. On a velamen-like tissue in the root cortex of orchids. Flora 185: 313-323.

Cabrera J, Barcala M, Fenoll C, Escobar C. 2014. Transcriptomic signatures of transfer cells in early developing nematode feeding cells of Arabidopsis focused on auxin and ethylene signaling. Frontiers in Plant Science 5: 1-9.

Carlsward BS, Stern WL, Bytebier B. 2006. Comparative vegetative anatomy and systematics of the angraecoids (Vandeae, Orchidaceae) with an emphasis on the leafless habit. Botanical Journal of the Linnean Society 151: 165-218.

Chatin AG. 1856. Anatomie des plantes aeriennes de l'ordre des Orchidees, 1, Memoire: Anatomie des raciness. Mémoires de la Société des Sciences Naturelles de Cherbourg 4: 5-18.

Chen XY, Kim JY. 2009. Callose synthesis in higher plants. Plant Signaling \& Behavior 4: 489-492.

Chomicki G, Bidel LP, Ming F, et al. 2015. The velamen protects photosynthetic orchid roots against UV-B damage, and a large dated phylogeny implies multiple gains and losses of this function during the Cenozoic. New Phytologist 205: 1330-1341. 
Cui W, Lee JY. 2016. Arabidopsis callose synthases CalS1/8 regulate plasmodesmal permeability during stress. Nature Plants 16034: 1-9.

Dycus AM, Knudson L. 1957. The role of the velamen of the aerial roots of orchids. Botanical Gazette 119: 78-87.

Engard CJ. 1944. Morphological identity of the velamen and exoderm in orchids. Botanical Gazette 105: 457-462.

Enstone DE, Peterson CA, Ma F. 2003. Root endoderm and exoderm: structure, function, and responses to the environment. Journal of Plant Growth Regulation 21: 335-351.

Feder N, O'Brien TP. 1968. Plant microtechnique: some principles and new methods. American Journal of Botany 55: 123-142.

Fernandez-Garcia N. 2009. Role of phi cells and the endoderm under salt stress in Brassica oleracea. New Phytologist 181: 347-360.

Figueroa C, Salazar GA, Zavaleta HA, Engleman EM. 2008. Root character evolution and systematics in Cranichidinae, Prescottiinae and Spiranthinae (Orchidaceae, Cranichideae). Annals of Botany 101: 509-520.

Fineran BA. 1998. Flange cells: a review. In: Bhatia B, Shkula AK, Sharma HL. (eds.) Plant form and function. New Delhi, Angkor Publishers. p. 111-132.

Fineran BA, Calvin CL. 2000. Transfer cells and flange cells in sinkers of the mistletoe Phoradendron macrophyllum (Viscaceae), and their novel combination. Protoplasma 211: 76-93.

Gama TSS, Aguiar-Dias ACA, Damaceno D. 2016. Transfer cells in trichomatous nectary in Adenocalymma magnificum (Bignoniaceae). Anais da Academia Brasileira de Ciências 88: 527-537.

Gunning BES, Pate JS. 1969. "Transfer cells" plant cells with wall ingrowths, specialized in relation to short distance transport of solutes: their occurrence, structure, and development. Protoplasma 68: 107-133.

Idris NA, Collings DA. 2015. The life of phi: the development of phi thickenings in roots of the orchids of the genus Miltoniopsis. Planta 241: 489-506.

Ingram G, Nawrath C. 2011. The roles of the cuticle in plant development: organ adhesions and beyond. Journal of Experimental Botany 68: 5307-5321.

Johansen DA. 1940. Plant microtechnique. New York, McGraw Hill Book.

Karremans AP. 2016. Genera Pleurothallidinarum, An updated phylogenetic overview of Pleurothallidinae. Lankesteriana 16: 219-241.

Kraus JE, Arduin M. 1997. Manual básico de métodos em morfologia vegetal. Rio de Janeiro, Seropédica.

Lee JY, Lu H. 2011. Plasmodesmata: the battleground against intruders. Trends in Plant Science 16: 201-210.

Leroux O, Bagniewska-Zadworna A, Rambe SK, et al. 2011. Non-lignified helical cell wall thickenings in root cortical cells of Aspleniaceae (Polypodiales): histology and taxonomical significance. Annals of Botany 107: 195-207.

Luna E, Pastor V, Robert J, Flors V, Mauch-Mani B, Ton J. 2011. Callose deposition: a multifaceted plant defense response. Molecular Plant Microbe Interact 24: 183-193.

McCurdy DW, Patrick JW, Offler CE. 2008. Wall ingrowth formation in transfer cells: novel examples of localized wall deposition in plant cells. Current Opinion in Plant Biology 11: 653-661.

Melo HC. 2011. Espessamento em fi de parede celular. Hoehnea 38: 1-7.

Miyashita N, Koga H. 2017. Three-dimensional ultrastructure of feeding tubes and interconnected endoplasmic reticulum in root-knot nematode-induced giant cells in rose balsam. Protoplasma 254: 941-1951.

Monjardino P, Rocha S, Tavares AC, et al. 2013. Development of flange and reticulate wall ingrowths in maize (Zea mays L.) endosperm transfer cells. Protoplasma 250: 495-503.

Murray JD, Cousins DR, Jackson KJ, Liu C. 2013. Signaling at the root surface: The role of cutin monomers in mycorrhization. Molecular Plant 6: 1381-1383.

Nawrath C. 2002. The biopolymers cutin and suberin, The Arabidopsis Book. American Society of Plant Biologists 1: e0021. doi: 10.1199/tab.0021

Nedukha OM. 2015. Callose: Localization, functions, and synthesis in plant cells. Cytology and Genetics 49: 49-57.
Nguyen STT, McCurdy DW. 2017. Wall ingrowth deposition in phloem parenchyma transfer cells in Arabidopsis: heteroblastic variations and a potential role in pathogen defence. Plant Signaling \& Behavior 12: $1-15$.

Nguyen ST, Greaves T, McCurdy DW. 2017. Heteroblastic development of transfer cells is controlled by the microRNA miR156/SPL Module. Plant Physiology 173: 1676-1691.

Offler CE, McCurdy DW, Patrick JW, Talbot MJ. 2002. Transfer cells: cells specialized for a special purpose. Annual Review of Plant Biology 54: 431-454.

Oudemans C. 1861. Ueber den Sitz der Oberhaut bei den Luftwurzeln der Orchideen. Verh Kon Ned Akad Wetensch 9: 1-32.

Pedroso-de-Moraes C, Souza-Leal TD, Brescansin RL, Pettini-Benelli A, Sajo MG. 2012. Radicular anatomy of twelve representatives of the Catasetinae subtribe (Orchidaceae: Cymbidieae) Anais da Academia Brasileira de Ciências 84: 455-467.

Porembski S, Barthlott W. 1988. Velamen radicum micromorphology and classification of Orchidaceae. Nordic Journal of Botany 8: 117-137.

Pridgeon AM. 1983. The velamen and exoderm of orchid roots. In: Arditti K. (ed.) Orchid biology, reviews and perspectives. Ithaca, Cornell University Press. p. 139-192.

Pridgeon AM, Cribb PJ, Chase MW, Rasmussen F. 1999. Genera Orchidacearum. Vol. 1: General Introduction, Apostasioideae and Cypripedioideae. Oxford, Oxford University Press.

Pridgeon AM, Stern WL, Benzing DH. 1983. Tilosomes in roots of Orchidaceae: morphology and systematic occurrence. American Journal of Botany 70: 1365-1377.

Reynolds ES. 1963 The use of the lead citrate at high pH as an electron -opaque stain in electron microscopy. The Journal of Cell Biology 17: 208-212.

Rocha S, Monjardino P, Mendonça D, et al. 2014., Lignification of developing maize (Zea mays L.) endosperm transfer cells and starchy endosperm cells. Frontiers in Plant Science 5: 102-112.

Sandford WW, Adanlawo I. 1973. Velamen and exoderm characters of West African epiphytic orchids in relation to taxonomic grouping and habitat tolerance. Botanical Journal of the Linnean Society 66: 307-321.

Schreiber L. 2010. Transport barriers made of cutin, suberin and associated waxes. Trends in Plant Science 15: 546-553.

Schreiber L, Franke RB. 2011. Endoderm and exoderm in roots. In eLS. Chichester, John Wiley and Sons.

Silva IV, Meira RMSA, Azevedo AA. 2010. Anatomia de raízes de espécies de Orchidaceae do Parque Estadual da Serra do Brigadeiro, Minas Gerais. Hoehnea 37: 147-161.

Silva IV, Oliveira RM, Rossi AAB, Silva AB, Oliveira DM. 2015. Use of anatomical root markers for species identification in Catasetum (Orchidaceae) at the Portal da Amazônia region, MT, Brazil. Acta Amazônica 45: 21-28.

Stern WL. 2014. Anatomy of the monocotyledons Vol. X: Orchidaceae. Oxford, Oxford University Press.

Stern WL, Carlswards BS. 2009. Comparative vegetative anatomy and systematics of Laeliinae (Orchidaceae). Botanical Journal of the Linnean Society 160: 21-41.

Stern WL, Judd WS. 2001. Comparative anatomy and systematics of Catasetinae (Orchidaceae). Botanical Journal of the Linnean Society 136: 153-178.

Stern WL, Judd WS. 2002. Systematic and comparative anatomy of Cymbidieae (Orchidaceae). Botanical Journal of the Linnean Society 139: 1-27.

Stern WL, Judd WS, Carlsward BS. 2004. Systematic and comparative anatomy of Maxillarieae (Orchidaceae), sans Oncidiinae. Botanical Journal of the Linnean Society 144: 251-274.

Talbot MJ, Franceschi VR, McCurdy DW, Offler CE. 2001. Wall ingrowth architecture in epidermal transfer cells of Vicia faba cotyledons. Protoplasma 215: 191-203.

Talbot MJ, Offler CE, McCurdy DW. 2002. Transfer cell wall architecture: a contribution towards understanding localized wall deposition. Protoplasma 219: 197-209. 
Talbot MJ, Wasteneys G, McCurdy DW, Offler CE. 2007a. Deposition patterns of cellulose microfibrils in flange wall ingrowths of transfer cells indicate clear parallels with those of secondary wall thickenings. Functional Plant Biology 34: 307-313.

Talbot MJ, Wasteneys GO, Offler CE, McCurdy DW. 2007b. Cellulose synthesis is required for deposition of reticulate wall ingrowths in transfer cells. Plant Cell Physiol 48: 147-158.

Thompson RD, Hueros G, Becker H, Maitz M. 2001. Development and functions of seed transfer cells. Plant Science 160: 775-783.

Tozin LRS, Rodrigues TM. 2017. Morphology and histochemistry of glandular trichomes in Lamiaceae. Acta Botanica Brasilica 31: 330-343.

Vatén A, Dettmer J, Wu S, et al. 2011. Callose biosynthesis regulates symplastic trafficking during root development. Developmental Cell 21: 1144-1155.
Wilson H, Mycock D, Weiersbye IM, Wilson H. 2017. The salt glands of Tamarix usneoides E, Mey, ex Bunge (South African Salt Cedar). International Journal of Phytoremediation 19: 587-595.

Xie B, Deng Y, Kanaoka MM, Okada K, Hong Z. 2012. Expression of Arabidopsis callose synthase 5 results in callose accumulation and cell wall permeability alteration. Plant Science 183: 1-8.

Zeier J, Ruel K, Ryser U, Schreiber L. 1999. Chemical analysis and immunolocalisation of lignin and suberin in endodermal and hypodermal/rhizodermal cell walls of developing maize (Zea mays L.) primary roots. Planta 209: 1-12.

Zotz G, Winkler U. 2013. Aerial roots of epiphytic orchids, the velamen radicum and its role in water and nutrient uptake. Oecologia 171: 733-741.

Zotz G. 2016. Plants on plants - The biology of vascular epiphytes. Berlin, Springer. 